\author{
DEMCHUK O.M., KARPOV P.A. ${ }^{\bowtie}$, RAYEVSKY A.V., OZHEREDOV S.P., SPIVAK S.I., \\ YEMETS A.I., BLUME Ya.B. \\ Institute of Food Biotechnology and Genomics of Natl. Acad. Sci. of Ukraine, \\ Ukraine, 04123, Kyiv, Osypovs'koho str., $2 \mathrm{~A}$ \\ 凶.karpov@nas.gov.ua,(050) 544-69-03
}

\title{
ALANINE SCANNING OF DINITROANILINE/PHOSPHOROTHIOAMIDATE SITE OF $\alpha$-TUBULIN IN PLASMODIUM SPECIES DISTRIBUTED IN INDIA
}

Aim. Identification of amino acid residues participating in specific binding of dinitroaniline and phosphorothioamidate compounds with $\alpha$-tubulin in Plasmodium falciparum. Methods. Protein structure modelling, protein structure optimization using molecular dynamics method, ligand-protein docking, alanine scanning mutagenesis. Results. Molecular docking of canonical compounds and alanine scanning mutagenesis, indicate two key (Arg2, Val250) and one minor (Glu3) residues involved in binding of both - dinitroaniline and phosphorothioamidate compounds. At the same time, it was revealed two minor residues (Asp251, Glu254) interacting only with some members of dinitroaniline grope. Conclusions. It was identified amino acid residues predetermining existence of joint site and similar interaction of $\alpha$-tubulin with dinitroaniline and phosphorothioamidate compounds in P. falciparum.

Keywords: malaria, Plasmodium, $\alpha$-tubulin, molecular interaction, dinitroanilines compounds, phosphorothioamidate compounds, alanine scanning mutagenesis.

Human malaria is a complex disease caused by numerous Plasmodium species, which threatens the half of Earth population. The control of malaria infection is hampered by many factors, including emerging of drug resistance. It is a fact that many of existing malaria therapeutics are increasingly ineffective and it is an urgent need in development of principally new therapeutic strategies and agents [1]. It should be noted that malaria is an important component of morbidity and mortality in the Republic of India. The National Vector Borne Disease Control Program of India reported $~ 1.6$ million cases and $\sim 1100$ malaria deaths in 2009 [2].

Malaria in India is known to be caused at least by four Plasmodium species: $P$. falciparum, $P$. vivax, $P$. ovale and $P$. malariae [3]. Two of them,
$P$. falciparum and $P$. vivax, are dominative in this area. $P$. malariae has been reported in the eastern India state of Orissa [4], while $P$. ovale appears to be extremely rare if not absent [2]. Among the aforementioned species $P$. falciparum is most severe strain of the malaria species correlated with almost every malarial death (CDC www.cdc.gov/malaria/about/disease.html). P. falciparum is strongly associated with severe disease syndrome known as cerebral malaria, which is associated with high mortality [2]. At the same time, it is known about the existence of different ecotypes and lines in both P. falciparum and its mosquito vector [3].

A number of drugs have been developed to treat malaria. However, with emergence of resistance, many of the previously effective substances have lost their relevance (quinine, chloroquine, amodiacin, pyrimethamine, etc.). Due to point mutations, Plasmodium increased resistance against complex drugs of antifolate type, of which sulfadoxine and pyrimethamine were the most commonly used [5].

During past decade years there has been a new growth of interest in tubulin as an important target for compounds with antiprotozoan activity. Several classes of microtubule (MT) inhibitors have demonstrated potent activity against malarial parasites in in vivo: vinblastine [6 - 8], dolastatin 10 [9], auristatins [10] and taxoids [11, 12]. Most of these agents have been demonstrated to disrupt or stabilize normal microtubular structures. Unfortunately, most all these compounds show toxicity to mammalian cells $[10,13]$ due to the interspecies conservation of tubulin [14]. P. falciparum and human $\alpha$-tubulins share $\sim 83 \%$ and $\beta$-tubulins $\sim 87 \%$ of identity. However it was found that human antimalarial drugs (e.g. sulfadiazine, sulfadoxine, pyrimethamine, cycloguanyl) were lethal for the model plant Arabidopsis thaliana at similar

\footnotetext{
○ DEMCHUK O.M., KARPOV P.A., RAYEVSKY A.V., OZHEREDOV S.P., SPIVAK S.I., YEMETS A.I., BLUME Ya.B.
} 
concentrations to commercial herbicides: glufosinate and glyphosate [15]. Although MT inhibitors from anticancer programs have proved useful in probing MT function in parasites, such nonselective agents have no prospects as antimalarial drugs $[13,14]$.

Previous studies have shown that dinitroaniline and phosphorothioamidates compounds, which are active against plant microtubules, are also active against $P$. falciparum, and may act as antimalarial drugs $[6,15]$. It indicates $\alpha$-tubulin as extremely promising molecular target in the case of parasitic diseases such as leishmaniasis and trypanosomiasis [16, 17]. In plants, phosphorothioamidates demonstrate effects, similar to dinitroanilines and bind to the same binding site. Phosphorothioamidates have similar effects on plants as the dinitroanilines and bind to the same molecular site. As phosphorothioamidates have a more than 100-fold higher solubility in aqueous solutions than dinitroanilines, these compounds are more promising candidates for modification than dinitroanilines, where biological studies indicated that maintaining high sufficient drug concentrations is difficult [18]. Therefore we consider dinitroaniline and phosphorothioamidate compounds as the most priority group for the search of new antimalarial agents.

The purpose of current study was application of alanine scanning mutagenesis for identification of amino acids playing key role in binding of dinitroaniline and phosphorothioamidates compounds with Plasmodium $\alpha$-tubulin.

\section{Materials and methods}

Structural model of $\alpha$-tubulin molecule from Plasmodium falciparum (TBA_PLAFK, UniProtKB: P14642) was built using protein structure homology-modelling server Swiss-Model [19]. The template modelling was based on template RCSB Protein Data Bank (www.rcsb.org) [19] structures: 5UBQ (A) - $\alpha$-tubulin from cilia of Tetrahymena thermophila (Cryo-EM structure) [21] and 2.5 E XRAY structure 5KX5 (A) of $\alpha$-tubulin from Ovis aries [22].

For protein structure geometry optimization we used minimization of potential energy based on steepest descent algorithm with a maximum number of steps $=1000$ and a gradient $=0.1$ of charmm 27 force field. All visualizations and analysis of PDB-structures and constructed model of Plasmodium $\alpha$-tubulin were performed using PyMOL v.1.5.0.5 software (www.pymol.org).
Alanine scanning mutagenesis was performed using VMD/NAMD software, enhanced with AlaScan plugin (Version 1.0) [23]. As the ligands we used 3D-models of 18 dinitroaniline and 4 phosphorothioamidates compounds.

Dinitroaniline compounds: Sulfamidas 16 (PubChem CID: 11282001), Sulfamidas21 (PubChem CID: 11235040), Sulfamidas20 (PubChem CID: 11199668), Sulfamidas23 (PubChem CID: 11177910), Sulfamidas33 (PubChem CID: 11177051), Sulfamidas24 (PubChem CID: 1116555), Sulfamidas25 (PubChem CID: 11155360), Benzenesulfonamide (PubChem CID: 10428592), CHEMBL80689 (PubChem CID: 10250523), CHEMBL78502 (PubChem CID: 10193905), Ethalfluralin (PubChem CID: 41381), Isopropaline (PubChem CID: 36606), Fluchloralin (PubChem CID: 36392), Prodiamine (PubChem CID: 34469), Dinitramide (PubChem CID: 34468), Profluralin (PubChem CID: 33500), Dipropalin (PubChem CID: 15966), Benfluralin (PubChem CID: 2319); and

$$
\text { Phosphorothioamidate compounds: }
$$

CHEMBL1835180 (PubChem CID: 56669570), CHEMBL1835273 (PubChem CID: 56659918), CHEMBL1835163 (PubChem CID: 14179764), Amiprophos (PubChem CID: 36612).

\section{Results and discussion}

Since our main task is the search for new effective inhibitors of Plasmodium $\alpha$-tubulin, it was necessary to identify key amino acids of joint dinitroaniline/phosphorothioamidate site that playing a key role in the ligand binding. One of the most common methods for such selection of amino acids important for protein-protein or protein-ligand interaction is the method of alanine scanning mutagenesis [24].

Alanine (Ala) scanning is a widely used mutagenesis approach in which residues in a target protein are systematically substituted for alanine at selected positions by site-directed mutagenesis (in silico as well as in genetical experiment). Substitution with alanine residues eliminates side-chain interactions without altering main-chain conformation or introducing steric or electrostatic effects, so is often the preferred choice for testing the contribution of specific side-chains while preserving native protein structure. In most cases, replacement of the native amino acid(s) with an alanine residue(s) does not change overall conformation of polypeptide chain, such as in the opposite cases of glycine or proline substitutions. Also, such replacement 
with alanine never is accompanied by electrostatic or steric effects. It is also known that alanine is very common in both internal and external regions of protein globules. Thus, such virtual "mutations", i.e. scanning with neutral alanine, make it possible to identify key amino acids important for enzyme active center, protein activity, or participating in protein-protein and protein-ligand interactions. Thus, the alanine scanning allows us to investigate the structural and functional aspects of proteinligand and protein-protein interactions [25, 26].

In current study, we used the full-atom model of $\alpha$-tubulin from P. falciparum (TBA_PLAFK, UniProtKB: P14642), and the library of canonical dinitroaniline/phosphorothioamidate ligands (22 compounds: trifluralin-, orizalin- and amiprophosmethyl-like compounds).

Initial ligand structures were obtained from the PubChem Compound database through searching of substances similar to known tubulin inhibitors of dinitroanilines/phosphorothioamidate group. Similar structures were selected based on Tanimoto Threshold (TT) in 90-95\% (in the case of triflu- ralin- and amiprophosmethyl-like compounds) and 95\% for orizalin-like compounds. Only structures for which the database contains information on their biological activity (Biological Test Results) were selected.

In this study we performed an alanine scanning for amino acid residues, which we selected earlier as associated with dinitroaniline/phosphorothioamidate binding site in Plasmodium $\alpha$-tubulin [26]. Current alanine scanning indicates two key (Arg2, Val250) and one minor (Glu3) residues involved in binding of both dinitroaniline and phosphorothioamidate compounds. At the same time, we revealed two minor residues (Asp251, Glu254) interacting only with some members of dinitroaniline group.

In this way, according to the results of alanine scanning, we revealed two important (\$\$) and one minor residue (\$) involved in the binding of both dinitroaniline and phosphorothioamidate compounds; as well as two minor residues (\#) that form hydrogen bonds only with some compounds from orizolin-like group (Table).

Table. Summary results of alanine scanning effect on the binding of dinitroaniline and phosphorothioamidate to the surface of $\alpha$-tubulin from Plasmodium falciparum

\begin{tabular}{|c|c|c|c|c|c|c|c|c|}
\hline \multicolumn{2}{|c|}{ Ligands from PubChem } & \multicolumn{7}{|c|}{ Tested residues } \\
\hline Grope of compounds & CID & $\begin{array}{c}\text { ARG2 } \\
\$ \$\end{array}$ & $\begin{array}{c}\text { GLU3 } \\
\$\end{array}$ & GLN133 & ARG243 & $\begin{array}{c}\text { VAL250 } \\
\$ \$\end{array}$ & ASP251 \# & GLU254\# \\
\hline \multirow{4}{*}{$\begin{array}{l}\text { Amiprofosmethyl- } \\
\text { like }\end{array}$} & 56669570 & $* * *$ & & & & $* * * *$ & & \\
\hline & 56659918 & $* * * *$ & & & & & & \\
\hline & 14179764 & $* * * *$ & $*$ & & & $* *$ & & \\
\hline & 36612 & $* * * * *$ & $*$ & & & $* * * *$ & & \\
\hline \multirow{10}{*}{ Orizalin-like } & 11282001 & * & $*$ & & & $* * * *$ & & \\
\hline & 11235040 & $*$ & & & & $* * *$ & & \\
\hline & 11199668 & $* *$ & & & & $* * *$ & $*$ & \\
\hline & 11177910 & $* * * * *$ & & & & $* * *$ & $* *$ & $*$ \\
\hline & 11177051 & $* *$ & & & & $* * * *$ & & \\
\hline & 11165550 & & & & & $* * *$ & $* *$ & $* *$ \\
\hline & 11155360 & $*$ & $*$ & & & $* * * *$ & & \\
\hline & 10428592 & $*$ & & & & $* *$ & $*$ & \\
\hline & 10250523 & $* * * *$ & & & & $* * * *$ & & \\
\hline & 10193905 & $* * * *$ & & $*$ & $*$ & $* * * *$ & & \\
\hline \multirow{8}{*}{ Trifluralin-like } & 41381 & $*$ & $*$ & & & $* * * *$ & & \\
\hline & 36606 & $* * *$ & $*$ & & & $* * *$ & & \\
\hline & 36392 & $*$ & $*$ & & & $* * *$ & & \\
\hline & 34469 & $* *$ & $*$ & & & $*$ & & \\
\hline & 34468 & & $*$ & & & $* * *$ & & \\
\hline & 33500 & $* *$ & $*$ & & & $* * * *$ & & \\
\hline & 15966 & $* *$ & $*$ & & & $* * * *$ & & \\
\hline & 2319 & $* *$ & $*$ & & & $* * * *$ & & \\
\hline
\end{tabular}

Notes: importance for binding by growth- * $>* *>* * *>* * * *>* * * * *$. 


\section{Conclusions}

These studies identify amino acid residues and interactions, predetermining existence of joint site and similar interaction of $\alpha$-tubulin with dinitroaniline and phosphorothioamidate compounds in $P$. falciparum. Alanine scanning mutagenesis indicate two key (Arg2, Val250) and one minor (Glu3) residues involved in binding of both - dinitroaniline and phosphorothioamidate compounds. At the same time, it was revealed two minor residues (Asp251, Glu254) interacting only with some members of dinitroaniline group. Despite existence of the general mechanism of dinitroaniline and phos- phorothioamidate binding, alternative interactions within the previously defined site are enough realistic. We assume that these differences can contribute total binding energy and predetermine variations in binding of studied compounds in the site. Our data indicate that in the case of dinitroaniline compounds such differences may be stronger than in the case of phosphorothioamidate.

This research was supported by grant of the Joint Ukraine-Indian Republic R\&D Projects in 2019-2021 initiated by the Ministry of Education and Science of Ukraine and The Department of Science \& Technology of Ministry of Science \& Technology, India.

\section{References}

1. World Malaria Report. Geneva: World Health Organization; 2017. https://www.who.int/malaria/publications/world-malariareport-2017/en/.

2. Das A., Anvikar A.R., Cator L.J., Dhiman R.C., Eapen A., Mishra N., Nagpal B.N., Nanda N., Raghavendra K., Read A.F., Sharma S.K., Singh O.P., Singh V., Sinnis P., Srivastava H.C., Sullivan S.A., Sutton P.L., Thomas M.B., Carlton J.M., Valecha N. Malaria in India: The Center for the Study of Complex Malaria in India. Acta Trop. 2012. Vol. 121 (3). P. $267-$ 273. doi: 10.1016/j.actatropica.2011.11.008.

3. Molina-Cruz A., DeJong R.J., Ortega C., Haile A., Abban E., Rodrigues J., Jaramillo-Gutierrez G., Barillas-Mury C. Some strains of Plasmodium falciparum, a human malaria parasite, evade the complement-like system of Anopheles gambiae mosquitoes. Proc. Natl. Acad. Sci. USA. 2012. Vol. 109 (28). P. E1957-1962. doi: 10.1073/pnas.1121183109.

4. Sharma S.K., Tyagi P.K., Padhan K., Upadhyay A.K., Haque M.A., Nanda N., Joshi H., Biswas S., Adak T., Das B.S., Chauhan V.S., Chitnis C.E., Subbarao S.K. Epidemiology of malaria transmission in forest and plain ecotype villages in Sundargarh District, Orissa, India. Trans. R. Soc. Trop. Med. Hyg. 2006. Vol. 100 (10). P. 917-925.

5. Karpov P.A., Demchuk O.M., Ozheredov S.P., Spivak S.I., Yemets A.I., Blume Ya.B. Conservation of dinitroaniline/phosphorothioamidate site of $\alpha$-tubulin in Plasmodium species distributed in India. Factors of the Experimental Evolution of Organisms. 2019. Vol. 24. P. 327-332. doi: 10.7124/FEEO.v24.1124.

6. Usanga E.A., O'Brien E., Luzzato L. Mitotic inhibitors arrest the growth of Plasmodium falciaprum. FEBS Lett. 1986. Vol. 209. P. 23-27.

7. Bell A., Wernli B., Franklin R.M. Effects of microtubule inhibitors on protein synthesis in Plasmodium falciparum. Parasitol. Res. 1993. Vol. 79. P. 146-152.

8. Dieckmann-Schuppert A., Franklin R.M. Compounds binding to cytoskeletal proteins are active against Plasmodium falciparum in vitro. Cell Biol. Int. 1989. Vol. 13. P. 411-418.

9. Nath J., Schneider I. Anti-malarial effects of the anti-tubulin herbicide trifluralin: studies in Plasmodium falciparum. Clin. Res. 1992. Vol. 40. P. 331A.

10. Fennell B.J., Carolan S., Pettit G.R., Bell A. Effects of the antimitotic natural product dolastatin 10, and related peptides, on the human malarial parasite Plasmodium falciparum. J. Antimicrob. Chemother. 2003. Vol. 51. P. 833-841.

11. Schrevel J., Sinou V., Grellier P., Frappier F., Guйnard D., Potier P. Interactions between docetaxel (Taxotere) and Plasmodium falciparum - infected erythrocytes. Proc. Natl. Acad. Sci. USA. 1994. Vol. 91. P. 8472-8476.

12. Pouvelle B., Farley P.J., Long C.A., Taraschi T.F. Taxol arrests the development of blood-stage Plasmodium falciparum in vitro and Plasmodium chabaudi adami in malaria-infected mice. J. Clin. Invest. 1994. Vol. 94. P. 413-417.

13. Bell A. Microtubule inhibitors as potential antimalarial agents. Parasitol. Today. 1998. Vol. 14. P. 234-240.

14. Fennell B.J., Naughton J.A., Dempsey E., Bell A. Cellular and molecular actions of dinitroaniline and phosphorothioamidate herbicides on Plasmodium falciparum: tubulin as a specific antimalarial target. Mol. Biochem. Parasitol. 2006. Vol. 145 (2). P. 226-238.

15. Corral M.G., Leroux J., Stubbs K.A., Mylne J.S. Herbicidal properties of antimalarial drugs. Sci. Repts. 2017. Vol. 7. P. 45871. doi: 10.1038/srep45871.

16. Robinson D.R., Sherwin T., Ploubidou A., Byard E.H., Gull K. Microtubule polarity and dynamics in the control of organelle positioning, segregation, and cytokinesis in the trypanosome cell cycle. J. Cell Biol. 1995. Vol. 128. P. 1163-1172.

17. Werbovetz K.A. Tubulin as an antiprotozoal drug target. Mini Rev. Med. Chem. 2002. Vol. 2. P. 519-529.

18. Dhooghe E., Van L.K., Eeckhaut T., Leus L., Van H.J. Mitotic chromosome doubling of plant tissues in vitro. Plant Cell Tiss. Org. Cult. 2011. Vol. 104. P. 359-373.

19. Waterhouse A., Bertoni M., Bienert S., Studer G., Tauriello G., Gumienny R., Heer F.T., de Beer T.A.P., Rempfer C., Bordoli L., Lepore R., Schwede T. SWISS-MODEL: homology modelling of protein structures and complexes. Nucl. Acids Res. 2018. Vol. 46 (W1). P. W296-W303.

20. Berman H.M., Westbrook J., Feng Z., Gilliland G., Bhat T.N., Weissig H., Shindyalov I.N., Bourne P.E. The Protein Data Bank. Nucl. Acids Res. 2000. Vol. 28 (1). P. 235-242. 
21. Ichikawa M., Liu D., Kastritis P.L., Basu K., Hsu T.C., Yang S., Bui K.H. Subnanometre-resolution structure of the doublet microtubule reveals new classes of microtubule-associated proteins. Nat. Commun. 2017. Vol. 8. P. 15035. doi: $10.1038 /$ ncomms 15035 .

22. Roy A., Kucukural A., Zhang Y. I-TASSER: a unified platform for automated protein structure and function prediction. Nature Protocols. 2010. Vol. 5. P. 725-738.

23. Liu P., Dehez F., Cai W., Chipot C. A toolkit for the analysis of free-energy perturbation calculations. J. Chem. Theor. Comput. 2012. Vol. 8. P. 2606-2616.

24. Simonsen S.M., Sando L., Rosengren K.J., Wang C.K., Colgrave M.L., Daly N.L., Craik D.J. Alanine scanning mutagenesis of the prototypic cyclotide reveals a cluster of residues essential for bioactivity. J. Biol. Chem. 2008. Vol. 283 (15). P. 98059813. doi: 10.1074/jbc.M709303200.

25. Howlader M.T., Kagawa Y., Miyakawa A., Yamamoto A., Taniguchi T., Hayakawa T., Sakai H. Alanine scanning analyses of the three major loops in domain II of Bacillus thuringiensis mosquitocidal toxin Cry4Aa. Appl. Environ. Microbiol. 2010. Vol. 76 (3). P. 860-865. doi: 10.1128/AEM.02175-09.

26. Gauguin L., Delaine C., Alvino C.L., McNeil K.A., Wallace J.C., Forbes B.E., De Meyts P. Alanine scanning of a putative receptor binding surface of insulin-like growth factor-I. J. Biol. Chem. 2008. Vol. 283 (30). P. 20821-20829. doi: 10.1074/jbc.M802620200.

ДЕМЧУК О.М., КАРПОВ П.А., РАСВСЬКИЙ О.В., ОЖЕРСДОВ С.П., СПІВАК С.І., СМЕЦЬ А.І., БЛЮМ Я.Б.

Інститут харчової біотехнологї та геноміки НАН України,

Україна, 04123, м. Київ, вул. Осиповського, 2 A

\section{АЛАНІНОВЕ СКАНУВАННЯ САЙТУ ЗВ'ЯЗУВАННЯ КАНОНІЧНИХ ДИНІТРОАНІЛІНІВ I ФОСФОРОТІОАМІДІВ 3 $\alpha$-ТУБУЛІНОМ PLASMODIUM FALCIPARUM}

Mema. Визначити амінокислотні залишки що відповідають за специфічне зв’язування похідних динітроаніліну і фосфоротіоаміду, на поверхні молекули $\alpha$-тубуліну Plasmodium falciparum. Memoди. Моделювання просторової структури білків за гомологією, оптимізація побудованих моделей за допомогою методів молекулярної динаміки, ліганд-білковий докінг, метод аланінового сканування. Результати. На підставі результатів молекулярного докінгу канонічних сполук і методу аланінового сканування було визначено два найбільш важливих (Arg2, Val250) та один мінорний (Glu3) амінокислотний залишки, залучені до процесу зв'язування як фосфоротіоамідів, так і динітроанілінів. Також було визначено два мінорні залишки (Asp251, Glu254), що здатні утворювати зв'язки лише з окремими представниками сполук ряду динітроаніліну. Висновки. За результатами дослідження було визначено амінокислотні залишки яки обумовлюють існування спільних механізмів ліганд-білкової взаємодії похідних динітроаніліну і фосфоротіоаміду з молекулою $\alpha$-тубуліну P. falciparum.

Ключові слова: малярія, Plasmodium, $\alpha$-тубулін, міжмолекулярна взаємодія, похідні динітроаніліну, похідні фосфоротіоаміду, аланінове сканування. 